DOI: 10.17707/AgricultForest.64.4.09

\author{
Liudmyla BUTSENKO, Antonina KALINICHENKO*, \\ Lidiia PASICHNYK, Iryna NEPRAN, Volodymyr PATYKA ${ }^{1}$
}

\title{
IDENTIFICATION OF PHYTOPATHOGENIC BACTERIA IN MAIZE SEEDS IN UKRAINE
}

\begin{abstract}
SUMMARY
The main bacterial diseases of maize: bacterial wilt of maize (Pantoea stewartii subsp. stewartii), goss's bacterial wilt (Clavibacter michiganensis subsp. nebraskensis), seed rot-seedling blight of maize (Bacillus subtilis), bacterial spot of maize (Pseudomonas syringae pv. syringae), bacterial leaf spot of maize (Pantoea agglomerans) and bacterial stalk rot of maize caused by several causative agents, were described. The causative agents of these diseases are often stored and transmitted with seeds, so seed analysis for the presence of phytopathogenic bacteria is an important step in the pathogen control system. For analysis, the corn seeds that were grown in the Poltava and Kiev regions of Ukraine were used. Microbiological analysis of seeds was carried out by classical methods. From visually healthy corn seeds, that form shoots in the field conditions, strongly affected by root rot, were isolated the strains of Pseudomonas fluorescens. Isolated $P$. fluorescens strains were the reason for the damage of soft rot in the field. This type of bacteria is an opportunistic pathogen and is capable of causing soft rot of a number of crops. It has been established that $P$. fluorescens cause root rot of maize seedlings. From visually healthy seeds, from which healthy corn seedlings form, Pantoea agglomerans and Pantoea ananatis were isolated. P. agglomerans are widespread plant epiphyte. $P$. ananatis causes disease symptoms in a wide range of economically important crops and forest tree species worldwide. It is regarded as a pathogen based on the increasing number of diseases reports on previously unrecorded hosts in different parts of the world and can cause damage to maize seedlings in the field.
\end{abstract}

Keywords: maize, seeds, bacterial diseases, Pantoea agglomerans, Pseudomonas fluorescens, Pantoea ananatis.

\section{INTRODUCTION}

Maize - is one of the main crops of modern world agriculture. This crop is of various uses and has high crop yield. About $20 \%$ of kernels of maize are used

\footnotetext{
${ }^{1}$ Liudmyla Butsenko, Lidiia Pasichnyk, Volodymyr Patyka, Department of Phytopathogenic Bacteria, Zabolotny Institute of Microbiology and Virology of National Academy of Sciences of Ukraine, UKRAINE; Antonina Kalinichenko* (corresponding author: akalinichenko@uni.opole.pl), Process Engineering Department; University of Opole, POLAND; Iryna Nepran, Department of Ecology, Kharkiv National Agrarian University, UKRAINE

Paper presented at the $9^{\text {th }}$ International Scientific Agricultural Symposium "AGROSYM 2018".

Notes: The authors declare that they have no conflicts of interest. Authorship Form signed online.
} 
for food requirements in the world, $15-25 \%$ are used for the technical purposes, in particular, the trunks and maize ears are used as alternative energy sources and nearly two-thirds is used for fodder. Corn ethanol is the most widely used biofuel in the USA and other countries.

Losses in the yield of maize from diseases are equal to 2-8 \%, and in some years may reach 15-20 \% (Gvozdyak et al., 2011). Loss of maize crops to major diseases and pests make up in southern Russia on average 25-30\% (Ivashchenko, 2010). The widespread use of pesticides leads to changes the pathogens composition of corn and an increase of bacterial diseases of plants (Patyka et al., 2016).

The main bacterial diseases of maize are the bacterial wilt of maize (Pantoea stewartii subsp. stewartii), goss's bacterial wilt and blight (Clavibacter michiganensis subsp. nebraskensis), seed rot-seedling blight of maize (Bacillus subtilis), bacterial spot of maize (Pseudomonas syringae pv. syringae), bacterial leaf spot of maize (Pantoea agglomerans) and bacterial stalk rot of maize caused by several causative agents (Gvozdyak et al., 2011).

Bacterial wilt of maize; pathogen name: Pantoea stewartii subsp. stewartii (Smith) Mergaert et al. Wilt of maize was newly diagnosed by F. Stewart in the USA in 1897. According to the official report European and Mediterranean Plant Protection Organization (EPPO) Stewart's wilt distributed on the American continent: Argentina, Bolivia, Canada, Mexico, Peru, Puerto Rico, United States of America. P. stewartii subsp. stewartii also detected in India, Korea, Benin, Togo. Stewart's wilt absents in Europe as of 11.04.2017 (EPPO Global Database, 2017). State service of Ukraine for food safety and consumer protection reported as of 01.01.2017 on the identifying bacterial wilt of corn in Ukraine (SSU, 2017).

The harmfulness of wilt is very big. Plants die in the case of infection of maize in the phase of underground seedlings. It is revealed that at average affection of plants, the yield decreases by $50-65 \%$. The planting of maize die almost completely during epiphytoties (OEPP/EPPO, 2016; Pataky, 2003). $P$. stewartii subsp. stewartii bacteria spread by the vessels of the whole plant, they get even into the root system and grain. From the vascular system they can get into the parenchymal tissue of leaves, stalk, damaging it. By accumulating in vessels, they occlude them and violate the water regime. Rate of spread of bacteria in the plant is connected with the speed of transpiration. The wilt is happening not only as the result of vascular occlusion, but also under the influence of toxin of polysaccharide nature, which are produced by $P$. stewartii subsp. stewartii. The bacteria that cause Stewart's wilt (P. stewartii subsp. stewartii) is vectored by corn flea beetles (Chaetocnema pulicaria) that overwinter in the soil and feed on young corn plants in the early season. The small, shiny black beetles are very active. Small percentage of these flea beetles survive the winter with the $P$. stewartii subsp. stewartii bacteria in their guts.

Management of Stewart's wilt. One of the most effective methods of protection is the pre-sowing treatment of corn seeds with insecticides and 
compliance with the schedules of insect protection measures throughout the growing season. It is shown that an effective method of $P$. stewartii subsp. stewartii control can be previous treatment of maize seeds with imuclopride.

Goss's bacterial wilt and blight; pathogen name: Clavibacter michiganensis subsp. nebraskensis (Vidaver et Mandel) Davis et al.. Disease was newly diagnosed on sugar maize in the USA (Nebraska State) in 1969, and later in other states throughout the Midwest, including Illinois, Wisconsin, and Iowa. It is the vascular disease by its symptoms, it practically doesn't differ from bacterial wilt of maize caused by P. stewartii subsp. stewartii (Mallowa et al., 2016).

Clavibacter michiganensis subsp. nebraskensis can survive on and in seed, and can be transmitted from seeds to seedlings. Seed-to-seedling transmission is low (about 2 percent), but infested seed may introduce the disease into new areas. Grass weeds such as green foxtail and shattercane can also serve as perennial hosts for the bacteria, and be a reservoir from which bacteria spread to corn plants. Low levels of the disease may go undetected until environmental conditions favor widespread disease (Wise et al., 2010).

Seed rot-seedling blight of maize; pathogen name: Bacillus subtilis (Ehrenberg) Cohn. In 1936 the seedling blight in Ukraine was discovered by $\mathrm{Ph}$. E. Nemlienko, who allocated the pathogen (Gvozdyak et al., 2011). The disease happens in the steppe and forest-steppe regions of Ukraine, in Russia, KabardinoBalkaria, Bashkiria, Uzbekistan and Georgia (Ivashchenko, 2010). Bacterial disease does great damage to seed maize: the storability of seeds and their viability worsen. The plants, which grew from infected seeds, retard in growth, especially during the first period of vegetation, the yield decreases by $20 \%$.

$B$. subtilis is the weak pathogen. Bacteria aren't capable to penetrate into the germ and the plant, which develops from it, therefore the disease isn't transmitted directly through the seeds to adult plant and from infected corn seeds to the healthy ones. The soil is the place of natural existence of $B$. subtilis. The leading role in the spread of infection is played by the capsid grain bug Trygonotylus ruficornis. The affection of ears by the causative agent of bacterial disease has direct correlation with the numbers of this insect. The especially dangerous is the number of capsid grain bug on the maize field in the stages of milky and the beginning of wax ripeness - the periods, most favorable for disease of plants.

Bacterial spot of maize; pathogen name: Pseudomonas syringae pv. syringae van Hall. Disease was newly diagnosed on the maize in Iowa State (USA) in 1916, later on sorghum and other sorghum plants (Gvozdyak et al., 2011). Maize is differently affected by the causative agent of red bacterial spot in different years and in different climatic conditions. At high temperature and intermediate moisture the spot on the leaves of maize appears before the heading of panicles (June-July) and affects $30-50 \%$ of plants. In the years with the large amount of precipitation and low temperature it appears later (August-September) and affects $15-30 \%$ of plants. Red bacterial disease almost doesn't appear on the 
maize in dry years. Stalk rot, which is caused by P. syringae pv. syringae, is characterized by great harmfulness, as the affected plants fail to produce. However, the extension of disease is small, as the single plants ( $-7 \%)$ are sometimes affected (Paccola-Meirelles et al., 2001).

$P$. syringae pv. syringae affects maize, sorghum and Sudan grass in all area of their cultivation. However, the Sudan grass and sorghum are more affected, than maize. The causative agent can be on the surface and in internal tissues of maize, sorghum and Sudan grass. The causative agent is spread by the seeds, and also by other cereals. In the case of artificial inoculation by $P$. syringae pv. syringae the symptoms of disease are observed on the millet, Siberian millet, foxtail, pale pigeon grass on the 4-5-th day (Ivashchenko, 2010).

Bacterial leaf spot of maize; pathogen name: Pantoea agglomerans (Beijerinck) Gavini et al. In cold summer months on leaf blades and sheaths of maize appear elongated spots, which at first are green and oily, and later they get light-brown coloring. Then the spots become roundish, oval or of irregular shape, with the yellowish aureole. Diameter of spot is $2-10 \mathrm{~mm}$. The brown center and red-brown brim are formed in the spots over time, from what the leaf blade gets the "burnt" look. At severe damage the plants stop the growth, and new leaves are small and chlorotic (Gvozdyak et al., 2011; Paccola-Meirelles et al., 2001).

Bacterial stalk rot of maize; stalk rot is caused by several causative agents (Gvozdyak et al., 2011):

1) Pectobacterium carotovorum subsp. carotovorum (Jones) Hauben et al.

Disease is characterized by full die-back of plants or their tops. The rot, which appears in the top part of the stalk in the place of initiation of panicles, can spread all over the stalk. The stalk has no signs of affection from external side. The rotting tissues of the stalk have very unpleasant smell. The affection of sprouts of maize by P. carotovorum subsp. carotovorum can reach $20 \%$. The especially large number of plants of maize is affected upon conditions of irrigating method of cultivation. The appearance of stalk rot on lateral shoots starts in the middle of August, at the same time the stalk looks healthy from outside, the central leaf, which is rolled and turned yellow, draws attention.

2) Enterobacter dissolvens (Rosen) Brenner et al.

Disease was newly diagnosed in the USA in 1919. The bacterial disease does great damage to the plantings of maize in America in certain years. The stalk rot of maize, which is caused by E. dissolvens, is widespread on the fields of the number of areas of Ukraine, Krasnodar Krai, in the North Caucasus, in some regions of Russia (Ivashchenko, 2010). This bacterial disease occurs only in certain years in small amounts, in the size, which doesn't exceed the tenth part of the percent. According to other researchers, the prevalence of E. dissolvens reached $20 \%$ in the Saratov region. Disease occurs on young and adults plants. Symptoms are mainly manifested on the plants in the first half of vegetative period, before they reach the height of $60-70 \mathrm{~cm}$. The temperature of $30-35 \square \mathrm{C}$ and high moisture helps in development of disease. In the years, when the amount of precipitation is insignificant, the rot gains the small sizes. In dry years 
the rot reaches $1-2 \%$. Yield losses in the years with precipitation above the norm reached $10-30 \%$.

E. dissolvens affects only maize. The causative agent gets into the plants through the water pores, stomata and various mechanical damages.

3) Dickeya zeae (Burkholder, McFadden et Dimock) Samson et al.

The stalk rot of maize, caused by D. zeae, was newly diagnosed by K. Sabet in Egypt in 1953. Later he described the similar disease in Southern Rhodesia and India. Soft rot of maize was also revealed in Hungary. The level of affection of maize was from 3 to $15 \%$. D. zeae is a major disease of maize in tropical and subtropical countries. It is particularly severe under conditions of high temperature and humidity. In temperate regions the disease is only a problem with overhead irrigation.

Leaf spot of maize; pathogen name: Pantoea ananas Mergaert, Verdonck et Kersters. Bacterial leaf spot of maize was newly diagnosed in Brazil in 1982. Nowadays the disease is widespread in all areas of cultivation of maize in Brazil and leads to substantial economic losses (Gvozdyak et al., 2011).

Since corn seeds can be a place of conservation of pathogenic bacteria and in the future serve as a source of plant infection, the aim of our work is, the identification of pathogenic bacteria on the seeds of corn grown in Ukraine.

\section{MATERIAL AND METHODS}

For analysis, the corn seeds that were grown in the Poltava and Kiev regions of Ukraine in 2016 - 2017 were inverted. The seeds were divided into two groups: Group 1- visually healthy seeds, which form in the field conditions shoots, are strongly affected by root rot, Group 2- visually healthy seeds, from which healthy corn seedlings are formed. Microbiological analysis of seeds was carried out by classical methods. The pathogenic properties of isolated bacterial isolates were determined by artificial inoculation of corn seedlings under laboratory conditions (Klement et al., 1990; Patyka et al., 2014).

To study the morphological and biochemical properties that are important for the identification of isolated bacteria, both the classical bacteriology methods (Klement et al. 1990; Patyka et al., 2014) and the API 20E test system (BioMerieux) are used. API 20E test-system contain tests to identify gramnegative facultative anaerobic rods.

\section{RESULTS AND DISCUSSION}

The investigated corn seeds were characterized by good germination (90\%) and no signs of seed bacterial damage were detected by visual inspection. However, seedlings from the seeds of Group 1 on the first, second sheet have brown spots that increase along the veins of the leaf.

In microbiological analysis, it was found that the seeds of Group 1, visually healthy seeds, which form in the field conditions shoots, are strongly affected by root rot, are predominantly inhabited by bacteria that form white or gray translucent colonies. While the seeds of Group 2, visually healthy seeds, 
from which healthy corn seedlings are formed, were dominated by bacteria that form yellow-pigmented colonies (Figure 1).

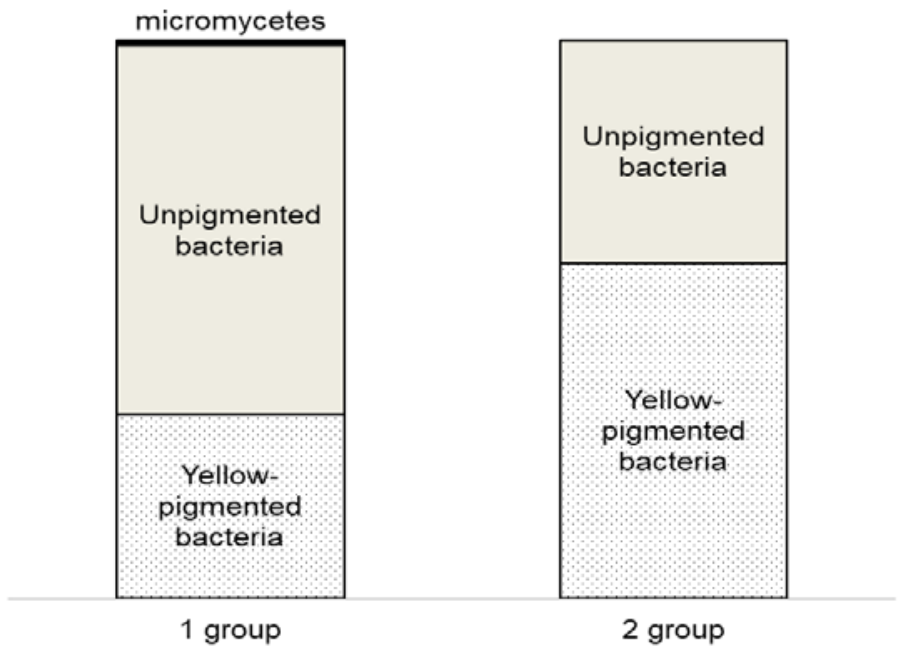

Figure 1. Bacterial biota of corn seeds

We selected all types of isolates from all the samples studied. A total of 70 isolates were selected. For the detection of phytopathogenic bacteria, pathogenic properties (artificial inoculation of maize seedlings in laboratory conditions) of all selected isolates were tested.

Among the unpigmented isolates that were isolated from the seeds of Group 1, five isolates were found that were pathogenic for maize. These isolates caused symptoms of bacterial damage on maize seedlings and maceration of tissues of potato tubers.

For identification of pathogenic isolates from seeds of Group 1 their morphological and physiological properties were studied. All isolates were gramnegative mobile aerobic rods (Table 1). Unpigmented pathogenic isolates from Group 1 maize seeds based on phenotypic properties were identified as Pseudomonas fluorescens. This type of bacteria is a oportunistic pathogen and is capable of causing soft rot of a number of crops.

Since one of the most dangerous causative agents of maize diseases belongs to the yellow-pigmented enterobacteria, we carefully analyzed all the yellow-pigmented isolates from both groups of seeds. 24 bacterial isolates on the basis of their morphological and biochemical properties were attributed to the genus Pantoea (Table 2).

Bacteria of the genus Pantoea are facultative anaerobic Gram-negative non-spore-forming oxidase-negative rods. Several species of bacteria which pathogenic for maize belong to this genus. First of all it is Pantoea stewartii subsp. stewartii. Also to the genus Pantoea belong species $P$. stewartii subsp. indologenes, $P$. ananatis and P. agglomerans (widespread plant epiphyte). 
Table 1. Cultural and physiological properties of phytopathogenic isolates from seeds Group 1 (visually healthy seeds)

\begin{tabular}{|l|c|c|}
\hline \multicolumn{1}{|c|}{ Test } & $\begin{array}{c}\text { Isolates from } \\
\text { maize seeds }\end{array}$ & $\begin{array}{c}\text { Pseudomonas } \\
\text { fluorescens (Boore } \text { et } \\
\text { Castenholz, 2005) }\end{array}$ \\
\hline The form of cells & Rods & Rods \\
\hline Gram's staining & - & - \\
\hline Motility Motile & Motile \\
\hline OF-test & Aerob & Aerob \\
\hline Pigment & - & - \\
\hline Fluorescent pigment & + & + \\
\hline Oxidase & + & + \\
\hline HR corn & + & + \\
\hline Pectinase & + & + \\
\hline $\begin{array}{l}\text { Artificial infection of } \\
\text { seedlings }\end{array}$ & - & - \\
\hline Arginine dihydrolase & - & + \\
\hline Lysine decarboxylase & + & - \\
\hline Formation of H2S and indole & - & + \\
\hline Utilization: & & + \\
\hline $\begin{array}{l}\text { D-glucose, D-melibiose, L- } \\
\text { arabinose }\end{array}$ & & \\
\hline $\begin{array}{l}\text { D-sorbitol, L-rhamnose, D- } \\
\text { sucrose, D-mannitol, } \\
\text { melibiose }\end{array}$ & & \\
\hline
\end{tabular}

Table 2. Cultural and physiological properties of yellow-pigmented isolates from maize seeds.

\begin{tabular}{|l|c|c|c|c|c|c|}
\hline \multicolumn{1}{|c|}{ Isolates } & $\begin{array}{c}\text { Yellow } \\
\text { pigment }\end{array}$ & $\begin{array}{c}\text { The form } \\
\text { of cells }\end{array}$ & $\begin{array}{c}\text { Gram's } \\
\text { staining }\end{array}$ & $\begin{array}{c}\text { Spore } \\
\text { formation }\end{array}$ & Oxidase & OF-test \\
\hline $\begin{array}{l}5 \text { isolates from } \\
\text { Group 1seeds }\end{array}$ & + & Rods & - & - & - & $\begin{array}{c}\text { Facultative } \\
\text { anaerobic }\end{array}$ \\
\hline $\begin{array}{l}17 \text { isolates from } \\
\text { Group 2 seeds }\end{array}$ & + & Rods & - & - & - & $\begin{array}{c}\text { Facultative } \\
\text { anaerobic }\end{array}$ \\
\hline $\begin{array}{l}\text { Genus Pantoea } \\
\text { Boore et } \\
\text { Castenholz, 2005) }\end{array}$ & + & Rods & - & - & - & $\begin{array}{c}\text { Facultative } \\
\text { anaerobic }\end{array}$ \\
\hline
\end{tabular}

In order to determine the species belonging of isolates, it was necessary to conduct additional tests to differentiate closely related species $P$. stewartii subsp. stewartii, $P$. stewartii subsp. indologenes, $P$. ananatis, $P$. agglomerans (Table 3) (Mergaert et al., 1993; Boore et Castenholz, 2005). On the basis of differentiating 
microbiological tests, isolates from maize seeds of the genus Pantoea were identified as Pantoea agglomerans and Pantoea ananatis (Table 4). All five isolates from the seeds of Group 1 belong to P. agglomerans. Three isolates from the seeds of Group 2 were identified as $P$. ananatis, 14 isolates from the seeds of Group 2 were identified as $P$. agglomerans.

Table 3. Tests for identification plant associated Pantoea(Mergaert et al., 1993;Boore et Castenholz, 2005)

\begin{tabular}{|l|c|c|c|c|}
\hline \multicolumn{1}{|c|}{ Test } & $\begin{array}{c}\text { Pantoea } \\
\text { stewartii } \\
\text { subsp. } \\
\text { stewartii }\end{array}$ & $\begin{array}{c}\text { Pantoea stewartii } \\
\text { subsp. indologenes }\end{array}$ & $\begin{array}{c}\text { Pantoea } \\
\text { ananatis }\end{array}$ & $\begin{array}{c}\text { Pantoea } \\
\text { agglomerans }\end{array}$ \\
\hline Motility & Non-motile & $\begin{array}{c}\text { Motile (or non- } \\
\text { motile) }\end{array}$ & Motile & Motile \\
\hline $\begin{array}{l}\text { Formation of } \\
\text { indole }\end{array}$ & - & + & + & - \\
\hline Nitrate reduction & - & - & - & + \\
\hline Esculin hydrolysis & - & + & $+/-$ & + \\
\hline $\begin{array}{l}\text { Acid production } \\
\text { from: } \\
\text { Maltose }\end{array}$ & - & + & + & + \\
\hline Salicin & - & + & + & + \\
\hline $\begin{array}{l}\text { Utilization of } \\
\text { citrate }\end{array}$ & - & + & + & - \\
\hline
\end{tabular}

Table 4. Differentially significant properties yellow-pigmented isolates from maize seeds.

\begin{tabular}{|l|c|c|c|}
\hline Test & $\begin{array}{l}5 \text { isolates from } \\
\text { Group 1 seeds }\end{array}$ & $\begin{array}{l}\text { 3 isolates from } \\
\text { Group 2 seeds }\end{array}$ & $\begin{array}{l}\text { 14 isolates from } \\
\text { Group 2 seeds }\end{array}$ \\
\hline Motility & Motile & Motile & Motile \\
\hline Formation of indole & - & + & - \\
\hline Nitrate reduction & + & - & + \\
\hline Esculin hydrolysis & + & - & - \\
\hline $\begin{array}{l}\text { Acid production } \\
\text { from: } \\
\text { Maltose }\end{array}$ & + & + & + \\
\hline Salicin & + & + & + \\
\hline Utilization of citrate & - & + & - \\
\hline
\end{tabular}

Systematic examination of maize crops is necessary for the timely detection of P. stewartii subsp. stewartii and other phytopathogenic bacteria (Khan et al., 1996). It must be remembered that the presence of phytopathogenic 
bacteria in seeds has no visual manifestation, therefore laboratory analysis is necessary to exclude the possibility of the appearance of these pathogens.

Visual assessment of seed quality can not be reliable. Since from visually healthy corn seeds, we isolated the pathogenic strains of $P$. fluorescens, which were the reason of the damage of soft rot of seedlings in the field.

Also from the seeds of corn without visible signs of damage we isolated bacteria of the Pantoea ananatis species. P. ananatis causes disease symptoms in a wide range of economically important agricultural crops and forest tree species worldwide. It is regarded as an emerging pathogen based on the increasing number of reports of diseases occurring on previously unrecorded hosts in different parts of the world. Its unconventional nature lies in the fact that, unlike the majority of plant pathogenic microbes, $P$. ananatis is capable of infecting humans and occurs in diverse ecological niches, such as part of a bacterial community contaminating aviation jet fuel tanks and contributing to growth promotion in potato and pepper (Gvozdyak et al., 2011).

$P$. ananatis is a common epiphyte; it also occurs endophytically in hosts where have been caused disease symptoms and in hosts where no such symptoms have been described (Coutinho et Venter, 2009).

\section{CONCLUSIONS}

From visually healthy corn seeds that are grown in Ukraine, Pantoea agglomerans, Pseudomonas fluorescens, Pantoea ananatis were isolated. It has been established that $P$. fluorescens cause root rot of maize seedlings.

\section{REFERENCES}

Boore, D.R., Castenholz R.W. (Eds) (2005): Bergey's manual of systematic bacteriology. (Editor-in-chief G.M. Garrity) V. 1, 2nd ed. NY, Berlin, Heidelberg, Springer, 2, Part B.

Coutinho T.A.., Venter S.N. (2009): Pantoea ananatis: an unconventional plant pathogen. Molecular Plant Pathology, Vol. 10 (3): 325-335.

EPPO Global Database. Pantoea stewartii. https://gd.eppo.int/taxon/ERWIST Accessed on 21.04.2018.

Gvozdyak R.I., Pasichnyk L.A., Yakovleva L.M. et al. (2011): Phytopatogenni bakterii. Interservis, Kyiv.

Ivashchenko, V.G. (2015): Diseases of maize: etiology, monitoring and problems of grade resistance. St.Petersburg-Pushkin, FGBNU VIZR. (Plant Protection News, Suppl.).

Khan, A., Ries, S.M., Pataky, J.K. (1996): Transmission of Erwinia stewartii through seed of resistant and susceptible field and sweet corn. Plant Diseases, Vol. 80 (4): 398-403.

Klement, Z., Rudollf, K., Sands, D. (1990): Methods in phytobacteriology. Budapest, Academia Kiado.

Mallowa, S.O., Mbofung G.Y., Eggenberger S.K. et al. (2016): Infection of maize by Clavibacter michiganensis subsp. nebraskensis does not require severe wounding. Plant Disease, Vol. 100 (4): 724-731. 
Mergaert, J., Verdonck, L., Kersters, K. (1993): Transfer of Erwinia ananas (synonym, Erwinia uredovora) and Erwinia stewartii to the Genus Pantoea emend. as Pantoea ananas (Serrano 1928) comb. nov. and Pantoea stewartii (Smith 1898) comb. nov., Respectively, and Description of Pantoea stewartii subsp. indologenes subsp. nov. International Journal of Systematic and Evolutionary Microbiology, Vol. 43: 162173 ,

Paccola-Meirelles, L.D., Ferreira, A.S., Meirelles, W.F. et al. (2001): Detection of a bacterium associated with a leaf spot disease of maize in Brasil. Journal Phytopathology, Vol. 149 (5): 275-279.

OEPP/EPPO (2016): Pantoea stewartii subsp. stewartii. OEPP/EPPO Bulletin, Vol. 46 (2): 226-236.

Pataky, J. (2003): Stewart's Wilt of Corn. APSnet Features. DOI: 10.1094/APSnetFeature-2003-0703.

Patyka, V., Buletsa, N., Pasichnyk, L., et al. (2016): Specifics of pesticides effects on the phytopathogenic bacteria. Ecological Chemistry and Engineering S, Vol. 23 (2), $311-331$.

Patyka, V.P., Pasichnyk, L.A., Dankevych, L.A., et al. (2014): Diagnostyka fitopatogennykh bacteriy. Metodychni rekomendatsii. Kyiv.

SSU - State service of Ukraine for food safety and consumer protection. (2017): An overview of the distribution of quarantine organisms in Ukraine (on 01.01.2017). http://www.consumer.gov.ua/ContentPages/Oglyad_Poshirennya_Karantinnikh_O rganizmiv_V_Ukraini/219/ Accessed on 21.04.2018.

Wise, K., Ruhl, G., Creswell, T. (2010): Goss's bacterial wilt and leaf blight. BP-81, W.Purdue University Extension. http://www.btny.purdue.edu Accessed on 19.06.2014. 